\title{
Oncogene FOS
}

National Cancer Institute

\section{Source}

National Cancer Institute. Oncogene FOS. NCI Thesaurus. Code C17440.

Retrovirus-associated DNA sequences (fos) orig inally isolated from the Finkel-BiskisJinkins (FBJ-MSV) and Finkel-Biskis-Reilly (FBR-MSV) murine sarcoma viruses. The protooncogene c-fos encodes a nuclear protein that dimerizes with Jun via a zipper motif to form the transcription factor AP1 and is involved in growth-related transcriptional control. The insertion of c-fos into FBJ-MSV or FBR-MSV induces osteogenic sarcomas in mice. The human c-fos gene is located at 14q21-3 on the long arm of chromosome 14. 